15

\title{
Монолитный мембранно-электродный блок на кремнии для микротопливного элемента
}

\author{
(ㄱ В.А. Юзова, Ф.Ф. Меркушев, О.В. Семенова \\ Сибирский фредеральный университет, Красноярск \\ E-mail: yuzovaV@yandex.ru
}

Поступило в Редакцию 28 марта 2017 г.

Сообщается о принципиальной возможности создания микротопливных элементов с монолитным кремниевым мембранно-электродным блоком, использующим в качестве каркаса пористую трехслойную структуру, сформированную двухсторонним анодным травлением пластины кремния толщиной $500 \mu \mathrm{m}$. Описывается технология получения мембранно-электродного блока.

DOI: 10.21883/PJTF.2017.16.44936.16797

В настоящее время энергетику будущего связывают с разработкой топливных элементов (ТЭ), в которых происходит прямое преобразование химической энергии в электрическую. Наиболее быстрорастущим рынком ТЭ является рынок микротопливных элементов (МТЭ), работающих в диапазоне малых мощностей (от сотен милливатт до десятков ватт). В разработках МТЭ в качестве основного варианта рассматриваются низкотемпературные воздушно-водородные элементы с твердополимерной протонпроводящей мембраной типа Nafion, электрически разделяющей два электрода: анод и катод. Каждый электрод представляет собой пористый слой с нанесенным на него катализатором (металлы платиновой группы). Система электродов и мембраны, называемая мембранно-электродным блоком (МЭБ), собирается в сандвичную структуру. Принцип работы такого МЭБ, химические реакции, происходящие на аноде и катоде, хорошо описаны в [1]. По мнению авторов этой работы, недостатком сборной конструкции МЭБ с мембраной типа Nafion является плохое сочетание со стандартными кремниевыми микротехнологиями, а изменение объема мембраны при увлажнении представляет большую проблему, особенно в процессе сборки с пористыми электродами. 
Перспективность использования кремния в качестве конструкционного материала при изготовлении МТЭ доказана многими исследованиями (см., например, [1-4]). Микроструктурирование кремния позволяет создавать газоподводящие каналы, пористые электроды, газодиффузионные слои, каркас для протонпроводящей мембраны, сепараторы для очистки газов, микронасосы, накопители энергии (суперконденсаторы), радиаторы для отвода тепла.

По этой причине в работе [1] была выдвинута оригинальная идея создания монолитной конструкции мембранно-электродного блока МТЭ, объединяющего в одной кремниевой пластине различные функциональные элементы (электроды и каркас протонпроводящей мембраны). Это дает основание надеяться на интегрирование монолитного МЭБ в единый кремниевый чип совместно с периферийными устройствами, а также электронными схемами.

Суть идеи заключалась в следующем. Изготавливался каркас МЭБ, который представлял собой трехслойную кремниевую структуру с переменной пористостью. Макропористые наружные слои играли роль электродов и обеспечивали газоподвод, а внутренний мезопористый слой с высоким сопротивлением для электронов создавал электроизоляцию между анодом и катодом, а также мог служить для формирования ионообменной мембраны. Трехслойная структура формировалась на пластине монокристаллического кремния последовательно: макропористый, мезопористый, макропористый слои, а для вскрытия пор слой монокристаллического кремния удалялся с пластины шлифованием или травлением в щелочном растворе.

Однако идея создания монолитного МЭБ не была доведена до практической реализации в силу сложности технологического процесса глубокого анодного травления кремния и получения структур со сквозными каналами на кремниевых пластинах стандартной толщины $(300-500 \mu \mathrm{m})$. Авторы ограничились получением электродных структур: сначала на упорядоченном макропористом кремнии с использованием затравочных центров [1], а позднее на неупорядоченном макропористом кремнии [5].

В настоящей работе сообщается о первой попытке практической реализации монолитной конструкции мембранно-электродного блока, созданного на основе кремниевой трехслойной пористой структуры толщиной $500 \mu \mathrm{m}$, и показывается принципиальная возможность работы такого МЭБ. 


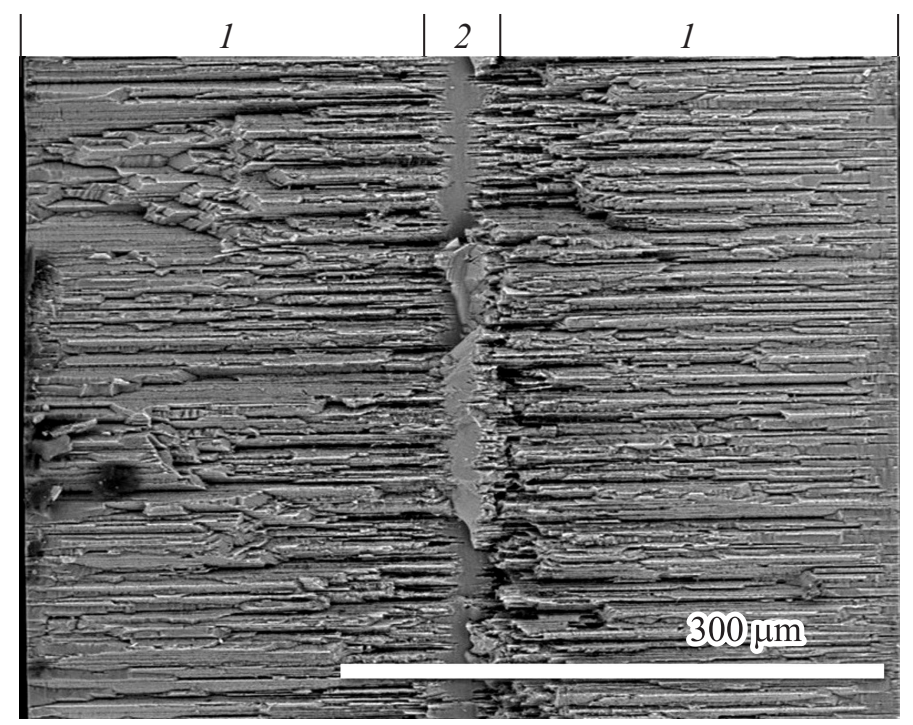

Рис. 1. Микрофотография общего вида трехслойной пористой структуры, сформированной на кремниевой пластине толщиной $500 \mu \mathrm{m} .1$ - макропористый слой, 2 - мезопористый слой.

Для исключения операций удаления монокристаллического слоя мы пошли по пути создания трехслойной пористой структуры, занимающей всю стандартную толщину кремниевой пластины (в нашем случае $500 \mu \mathrm{m})$, применив двухстороннее анодное травление. Другой мотивационной причиной увеличения толщины структуры явилась возможность наращивания суммарной поверхности электродов при одинаковой их площади за счет увеличения глубины пор. В работе [3] сообщалось, что внедрение катализатора в глубь пор повышает коэффициент его использования и, следовательно, эффективность работы МТЭ. Кроме того, двухстороннее травление облегчает процесс создания идентичной структуры обоих электродов, так как они формируются одновременно и в одинаковых условиях.

В своих экспериментах мы использовали полированную с обеих сторон пластину монокристаллического кремния (100) $n$-типа электро-

6 Письма в ЖТФ, 2017, том 43, вып. 16 
проводности с удельным сопротивлением в пределах $8 \Omega \cdot \mathrm{cm}$. На ее основе по технологии, описанной в [6], электрохимическим двухсторонним травлением была сформирована трехслойная пористая структура (рис. 1) в виде пятна площадью $0.8 \mathrm{~cm}^{2}$, расположенная в середине образца размером $15 \times 15 \mathrm{~mm}$.

Электронно-микроскопические исследования трехслойной структуры (Hitachi TM-1000 и JEOL SM 7001F) позволили выявить, что она занимает всю толщину кремниевой пластины и состоит из двух слоев макропористого кремния толщиной 245-249 $\mu \mathrm{m}$ с диаметром цилиндрических пор $0.5-10 \mu \mathrm{m}$ и расположенного между ними слоя мезопористого кремния толщиной $2-10 \mu \mathrm{m}$ с диаметром пор 50-100 nm. Нам не удалось в мезопористом слое выявить четкую форму пор. Центральные цилиндрические поры в слоях макропористого кремния были хорошо разделены между собой, но их характерной особенностью являлось наличие перпендикулярных боковых ответвлений диаметром 50-100 nm (рис. 2,a). Полученная трехслойная пористая структура служила остовом (каркасом) для изготовления кремниевого монолитного мембранно-электродного блока МТЭ.

Сначала на слоях макропористого кремния формировались каналы подачи топлива (водорода) и окислителя (кислорода). Центральные поры большого диаметра в макропористых слоях являются хорошим газотранспортным средством. Но боковые ответвления от центральных пор приводят к газотранспортным потерям, и в них создаются дополнительные механические напряжения, которые могут привести к разрушению хрупкого пористого электрода. Поэтому они закрывались по всей длине центральных пор путем электрохимического осаждения никеля из электролита состава $0.6 \mathrm{M} \mathrm{NiSO}_{4} \cdot 7 \mathrm{H}_{2} \mathrm{O}+0.3 \mathrm{M} \mathrm{H}_{3} \mathrm{BO}_{3}$ в результате подбора технологических режимов, которые не позволяли перекрыть металлом центральные поры по всему диаметру и закрыть поры на фронтальных поверхностях электродов. Кроме того, подбором длительности процесса осаждения можно регулировать глубину осаждения металла в мезопоры, закрывая только вход в них. Никель выбирался в качестве модельного материала, технология осаждения которого хорошо отработана. В этой части работы мы руководствовались результатами, полученными авторами [7], которые сообщали о возможности электрохимического осаждения никеля в поры большого диаметра с формированием в них трубок различной длины с толщиной стенок

Письма в ЖТФ, 2017, том 43, вып. 16 


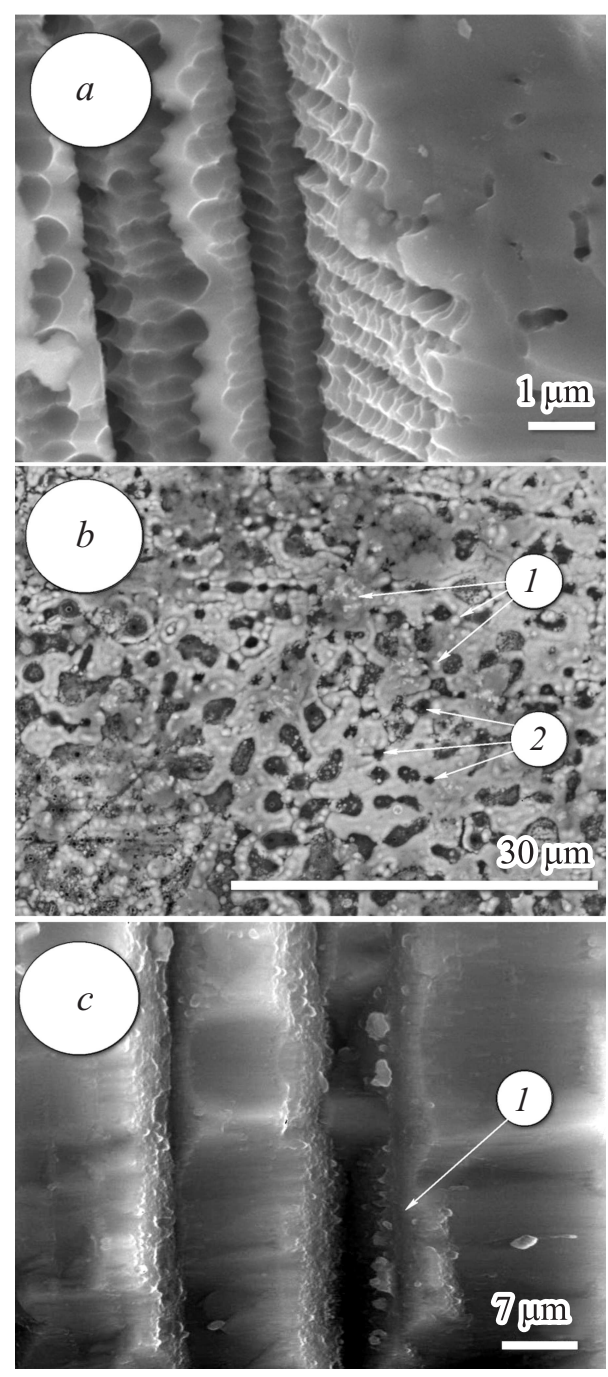

Рис. 2. Микрофотографии скола $(a, c)$ и поверхности $(b)$ электродных слоев макропористого кремния: $a$ - до осаждения металлов, $b, c$ - после осаждения металлов. 1 - частицы Ir, 2 - поры.

$6^{*}$ Письма в ЖТФ, 2017, том 43, вып. 16 
$0.2-0.4 \mu \mathrm{m}$ без образования сплошного металлического покрытия на поверхности макропористых слоев, в то время как поры нанометрового размера закрываются металлом по всему диаметру. Таким образом, нам удалось создать хорошие условия для газотранспорта в макропористом кремнии за счет сглаживания стенок центральных пор и заполнения металлом боковых ответвлений нанометрового диаметра, а также обеспечить барьерные свойства для прохождения газов через мезопористый слой.

Далее для формирования металлических контактов к МЭБ на поверхности всего образца размером $15 \times 15 \mathrm{~mm}$, включая области макропористых электродных слоев, термовакуумным испарением никеля наносились тонкие (не более $0.1 \mu \mathrm{m}$ ) пленки, не препятствующие подаче газов в поры, а затем только на электроды МЭБ площадью $0.8 \mathrm{~cm}^{2}$ осаждался катализатор. Для демонстрации работоспособности МЭБ в качестве катализатора использовался иридий. Осаждение Ir проводилось из раствора хлориридата аммония $\left(\mathrm{NH}_{4}\right)_{2} \mathrm{IrCl}_{6}$. При осаждении в результате реакции

$$
\left(\mathrm{NH}_{4}\right)_{2}\left[\mathrm{IrCl}_{6}\right]+2 \mathrm{Ni}=2 \mathrm{NH}_{4} \mathrm{Cl}+2 \mathrm{NiCl}_{2}+\mathrm{Ir}_{\downarrow}
$$

происходило замещение части никеля иридием. Ni переходил в раствор, a Ir восстанавливался на поверхности образца и пор в виде отдельных частиц.

Микрофотографии поверхности и скола одной из сторон МЭБ после осаждения металлов представлены на рис. $2, b$ и $c$ соответственно. Рис. $2, b$ показывает наличие на поверхности макропористого кремния пленки металлов $\operatorname{Ir}$ и $\mathrm{Ni}$, которая не закрывает газотранспортные поры в макропористом кремнии. На пленке никеля (рис. 2, $b$ и $c$ ) просматриваются вкрапления иридия. На рис. 2, $c$ хорошо видны поры без боковых ответвлений, доступные для транспорта водорода и кислорода.

Протонпроводящей мембраной служил высокоомный (удельное сопротивление в пределах $\left.10^{7} \Omega \cdot \mathrm{cm}[1]\right)$ мезопористый слой. Никаких дополнительных манипуляций для увеличения протонной проводимости этого слоя мы не предпринимали, считая, что при длительном анодном травлении поверхность кремния в порах значительно окислена, а остатки водного раствора плавиковой кислоты из толщи кремниевого материала в $249 \mu \mathrm{m}$ невозможно удалить без 
вакуумирования и сушки. Наличие воды обеспечивает образование двойного электрического слоя и протонную проводимость мезопористого слоя, a $\mathrm{SiO}_{2}$ способствует поддержанию водного баланca $[8]$.

Для проверки работоспособности полученного монолитного МЭБ нами был создан макет МТЭ, включающий системы получения водорода и кислорода, их подачу на электроды МЭБ. Напряжение, генерируемое МТЭ, снималось с противоположных поверхностей кремниевого образца, на котором был сформирован МЭБ. Ограниченный объем статьи не позволяет подробно изложить данные исследования. Они являются предметом другой работы. Здесь мы сообщаем лишь, что измеренная удельная мощность МТЭ для выдаваемого напряжения, равного $6 \mathrm{mV}$, при подаче водорода и кислорода на соответствующие электроды МЭБ под давлением, близким к атмосферному, составила величину $16 \mathrm{~mW} / \mathrm{cm}^{2}$. Конечно, величина мощности не удовлетворяет современным требованиям, но элемент стабильно работал в течение часа, пока не прекратилась подача газов. Это указывает на принципиальную возможность создания микротопливных элементов с монолитными кремниевыми МЭБ, использующими в качестве каркаса пористые трехслойные структуры, сформированные путем двухстороннего анодного травления пластин кремния толщиной $500 \mu \mathrm{m}$.

Работа выполнена по открытому плану Сибирского федерального университета.

\section{Список литературы}

[1] Астрова Е.В., Нечитайлов А.А., Забродский А.Г. // Альтернативная энергетика и экология. 2007. № 2 (46). С. 60-65.

[2] Гринберг В.А., Скундин А.М. // Электрохимия. 2010. Т. 46. № 9. С. $1027-$ 1043.

[3] Chun Y.G., Peck D.H., Kim C.S., Shin D.R. // J. New Mater. Electrochem. Systems. 2001. V. 4. N 1. P. 31-35.

[4] Забродский А.Г., Гуревич С.А., Кохеевин В.М., Астрова Е.В., Нечитайлов А.А., Сресели О.М., Теруков Е.И., Компан М.Е. // Альтернативная энергетика и экология. 2007. № 2 (46). С. 54-59.

[5] Преображенский Н.Е., Астрова Е.В., Павлов С.И., Воронков В.Б., Румянцев А.М., Жданов В.В. // ФТП. 2017. Т. 51. В. 1. С. 79-88.

Письма в ЖТФ, 2017, том 43, вып. 16 
[6] Юзова В.А., Меркушев Ф.Ф., Ляйком У.А. // Изв. вузов. Материалы электронной техники. 2014. В. 1. С. 8-12.

[7] Долгий А.Л., Холостов К.И. // Актуальные проблемы физики твердого тела. Сб. докл. Междунар. науч. конф. 20-23 окт. 2009 г. Минск: Изд. центр БГУ, 2009. T. 2. 344 c.

[8] Иванчев С.С., Мякин С.В. // Успехи химии. 2010. Т. 79. В. 2. С. 117-134. 